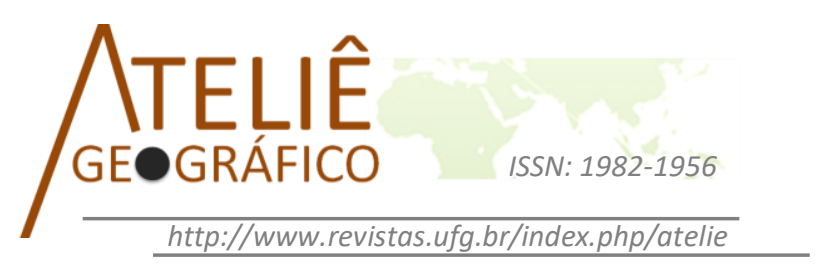

\title{
Contribuições para o Plano de Manejo de propostas de Unidades de Conservação em Santa Maria/RS
}

\section{Contribuciones para el Plan de Manejo de propuesta de Unidades de Conservación en Santa Maria/RS}

\section{Contributions for the Management Plan of proposal of Conservation Units in Santa Maria/RS}

\author{
Eliane Maria Foleto \\ Universidade Federal de Santa Maria \\ efoleto@gmail.com \\ Patrícia Ziani \\ Universidade Federal de Santa Maria \\ pathyziani@hotmail.com
}

\begin{abstract}
Resumo
Esse trabalho tem o objetivo de realizar estudos técnicos de zoneamento ambiental para subsidiar diretrizes para o plano de manejo nas áreas do Parque São Vicente Pallotti e Parque do Morro. Para tanto, confeccionaram-se mapas temáticos, os quais permitiram a identificação, caracterização e mapeamento das diferentes paisagens e das articulações o que subsidiou a proposta de um zoneamento e, elaboração de diretrizes para o plano de manejo. Portanto, foi possível constatar que em razão das áreas de estudo se localizarem quase que totalmente no perímetro urbano de Santa Maria elas sofrem corriqueiramente pressões em relação à expansão urbana e especulação imobiliária. Ressalta-se também que ambas as áreas dos Parques estão na Reserva da Biosfera da Mata Atlântica. Diante desse resultado e dos demais, geraram-se ainda os mapas de zoneamento ambiental. Por fim, acredita-se que a implantação de UCs nas áreas de estudo seja determinante para a conservação dessas áreas.

Palavras-chaves: Unidades de Conservação. Parque São Vicente Pallotti. Parque do Morro. Santa Maria.

\section{Resumen}

Este trabajo objetiva realizar estudios técnicos de división en zonas ambientales para subsidiar directrices para el plan de manejo en las áreas del Parque São Vicente Palotti y Parque del Morro. Así que, se confeccionaron mapas temáticos, los cuales permitieron la identificación, caracterización y levantamiento cartográfico de los diferentes paisajes y de las articulaciones lo que subsidió la propuesta de una división de zonas ambientales y, elaboración de directrices para el plan de manejo. Por lo tanto, fue posible constatar que en razón de las áreas de estudio localizarse casi que totalmente en el perímetro urbano de Santa
\end{abstract}


Maria ellas sufren rutinariamente presiones en relación a la expansión urbana y especulación inmobiliaria. Se resalta también que ambas las áreas de los Parques están en la Reserva de la Biosfera de la Mata Atlántica. Delante de esos resultados y de los demás, se generaron aún los mapas de división de zonas ambientales. Por fin, se cree que la implementación de UCs en las áreas de estudio sea determinante para la conservación de esas áreas.

Palabras-clave: Unidades de Conservación. Parque São Vicente Pallotti. Parque do Morro. Santa Maria.

\begin{abstract}
This work aims to perform technical studies of environmental zoning to subsidize guidelines for the management planting in areas of Parque São Vicente Pallotti and Parque do Morro. For this, we made thematic maps, which allowed the identification, characterization and mapping of different landscapes and the articulations, what subsidized the proposal of a zoning and, elaboration of guidelines for the management planting. Therefore, it was possible to observe that because the areas of study are located almost totally in the urban perimeter of Santa Maria they suffer pressures routinely in relation to the urban expansion and property speculation. We also highlight that both areas of the parks are in Biosphere Reserve of the Atlantic Forest. Before this result and the others, it was still generated the maps of environmental zoning. Finally, we believe that the implantation of Conservation Units in the areas of study is determinant for the conservation of these areas.

Keywords: Conservation Units. Parque São Vicente Pallotti. Parque do Morro. Santa Maria.
\end{abstract}

\title{
Introdução
}

Atualmente emerge uma atitude nova e diferenciada em favor da conservação dos ecossistemas e defesa do patrimônio natural, isto é, o executivo municipal de Santa Maria preocupado com a proteção destes espaços, institui em 2010 um Grupo de Discussão sobre Parques Urbanos e Unidades de Conservação, mas, percebe-se uma carência de informações técnicas acerca de Unidades de Conservação (UCs), a qual é agravada pelo fato de que, a sociedade santa-mariense não reconhece o patrimônio natural e remanescentes de Mata Atlântica, inseridas no tombamento da Reserva da Biosfera da Mata Atlântica (RBMA), definida com área prioritária para instituir UCs no Estado do Rio Grande do Sul (RS). Além disso, está o fato de que ambas são as únicas propostas da modalidade de UC de proteção integral na região central do Estado do RS. Sob essa realidade, tem-se como objetivo geral realizar estudos técnicos de zoneamento ambiental para subsidiar diretrizes para o plano de manejo nas áreas do Parque do Morro (156 hectares) e Parque São Vicente Pallotti (6,323 hectares). Para consolidar esse objetivo têm-se os seguintes objetivos específicos:

- Fundamentar teoricamente a temática de Áreas Protegidas;

- Caracterizar fisicamente o espaço de uma grande área com a definição da geomorfologia, rede de drenagem e vegetação visando identificar os atributos naturais;

- Propor para as áreas de estudo o zoneamento segundo a metodologia do IBAMA. 
- Analisar a tipologia mais adequada para estes espaços, buscando o enquadramento compatível com categorias de UCs propostas pelo Sistema Nacional de Unidades de Conservação da Natureza (SNUC).

Assim, espera-se auxiliar e aprofundar as discussões sobre as instituições dessa UCs em Santa Maria bem como contribuir na divulgação de informações relacionadas a essas áreas.

\section{Referencial teórico}

A partir da problemática ambiental gerada pelas ações predadoras e exploratórias dos seres humanos, no transcorrer da história, a sociedade e o Poder Público, de modo geral, passaram a perceber e compreender melhor a importância da proteção da natureza surgindo assim, uma atenção voltada para as Áreas Protegidas. Portanto, criam-se ações e diretrizes que almejam o controle de uso sobre áreas que carecem ser preservadas, conservadas e restauradas a fim de certificar que seja mantido seu equilíbrio ambiental.

As Áreas Protegidas podem ser compreendidas de várias maneiras, abarcando uma ampla gama de terminologias na literatura. Sob essa perspectiva, pode-se identificar na legislação ambiental brasileira a existência de distintas áreas com responsabilidade de proteção da biodiversidade biológica e dos recursos naturais, sendo legalmente protegidas como, por exemplo: as Áreas de Preservação Permanente (APPs), a Reserva Legal (RL) e as Unidades de Conservação (UCs). Sobre essa legislação destaca-se ainda a Lei no 6.938/1981 que institui a Política Nacional do Meio Ambiente (PNMA) que corrobora a criação dessas áreas como um de seus principais instrumentos (BRASIL, 1981).

Neste artigo objetiva-se destacar as áreas protegidas responsáveis pela proteção dos recursos naturais, em especial áreas protegidas cujo propósito é a proteção da biodiversidade, ecossistemas e paisagem, isto é, UCs que, conforme, o SNUC, Lei $n^{\circ} 9.985 / 2000$, são deliberadas como:

espaço territorial e seus recursos ambientais, incluindo as áreas
jurisdicionais, com características naturais relevantes, legalmente
instituído pelo Poder Público, com objetivos de conservação e limites
definidos, sob regime especial de administração, ao qual se aplicam
garantias adequadas de proteção (BRASIL, 2000, n.p.).

O SNUC é constituído por um conjunto de UCs federais, estaduais e municipais que se divide em dois grandes grupos, isto é:

- UCs de Proteção Integral: buscam preservar a natureza permitindo unicamente o uso indireto dos recursos naturais e apenas atividades de recreação, lazer e pesquisas científicas. Competem a esse grupo as categorias Estação Ecológica, Reserva Biológica, Parque Nacional, Monumento Natural e Refúgio de Vida Silvestre (BRASIL, 2000). 
- UCs de Uso Sustentável: permitem o uso direto dos recursos naturais, consentindo a exploração destes de maneira sustentável sem por em risco os recursos e processos ecológicos. Encontram-se nesse grupo as categorias: Área de Proteção Ambiental, Área de Relevante Interesse Ecológico, Floresta Nacional, Reserva Extrativista, Reserva de Fauna, Reserva de Desenvolvimento Sustentável e Reserva Particular de Patrimônio Natural. (BRASIL, 2000).

Sob essa perspectiva, vale ressalta-se que toda UC é uma área protegida, contudo nem toda área protegida pode ser considerada uma UC. Essa duas terminologias não podem ser utilizadas como sinônimos, pois ambas possuem dinâmicas e manejos diferentes. Concomitantemente a isso, destaca-se ainda para outra confusão conceitual, no entanto agora voltada ao conceito de Parque como UC que é corriqueiramente utilizado de forma errônea como sinônimo de Parque Urbano, quando dada UC pertencente à categoria Parque encontra-se em perímetro urbano. Não obstante, objetivando esclarecer tal ideia ressalta-se que um Parque Urbano, segundo PEREIRA LIMA (1994 apud LOBODA, DE ANGELIS 2005, p.133), é: "uma área verde, com função ecológica, estética e de lazer, no entanto com uma extensão maior que as praças e jardins públicos”. Já um Parque como UC, segundo o SNUC, conceitua-se como:

\footnotetext{
Espaço territorial e seus recursos ambientais, incluindo as águas jurisdicionais, com características naturais relevantes, legalmente instituído pelo Poder Público, com objetivos de conservação e limites definidos, sob regime especial de administração, ao qual se aplicam garantias adequadas de proteção (BRASIL, 2000, n.p.).
}

Possivelmente, pode-se associar essa confusão conceitual em razão de que as primeiras UCs instituídas no Brasil serem Parques Nacionais, os quais, inicialmente, contentavam critérios estéticos; após, atribuíram-se critérios técnicos para essa definição conforme aponta Bensusan (2006). Portanto, compreende-se que apesar dessas contradições conceituais, ambos os parques proporcionam diversos benefícios diretos ou indiretamente a população.

\section{Reserva da Biosfera Mata Atlântica (RBMA)}

A RBMA é uma das políticas públicas para a conservação do meio ambienta que foi inserida pela Organização das Nações Unidas para a Educação a Ciência e a Cultura (UNESCO), em 1968, chamado "O Homem e a Biosfera" (Man and the Biosphere Programme - MaB), que visa o estabelecimento de uma base científica que dê suporte a melhores relações entre sociedade e natureza a nível global. Diante disso, a partir de 1976 foram criadas Reservas da Biosfera, desempenhando um importante papel na conservação de ecossistemas e buscando estancar o ritmo cada vez mais rápido da extinção de espécies (CORRÊA, 1996). Destaca-se também que essas reservas são um exemplo de gestão integrada, participativa e sustentável dos recursos naturais, com os objetivos principais voltados a preservação da diversidade biológica, o 
desenvolvimento de atividades de pesquisa, o monitoramento ambiental, a educação ambiental, o desenvolvimento sustentável e a melhoria da qualidade de vida das populações.

Ressalta-se que existem Reservas da Biosfera em diversos biomas e relevos, incluindo: montanhas, ilhas e ambientes costeiros, florestas tropicais (como na Amazônia e Mata Atlântica), terras secas, áreas urbanas, savanas e agroecossistemas. Todas estas, estão delimitadas sob um sistema de zoneamento com Zonas Núcleo, de Transição e de Amortecimento (CORRÊA, 1996).

Sabe-se que todos os biomas brasileiros diariamente sofrem constantes ameaças, principalmente devido às pressões antrópicas. Diante disso, buscando reforçar a proteção desses biomas, o Plano Estratégico Nacional de Áreas Protegidas (PNAP), aponta que a presença dos mesmos é referência para a criação de UCs, pois se considera essas áreas como um hot spot em razão a elevada biodiversidade ali presente e por estarem sob pressão antrópica ficando assim, vulneráveis a extinção. Logo, evidencia-se que entre esses biomas, o que mais se encontra ameaçado de extinção, em razão à sua extensão territorial é o da Mata Atlântica, bioma presente em ambas às áreas de estudo.

Outro aspecto que salienta a conservação do bioma Mata Atlântica é uma das políticas do Governo do Estado do Rio Grande do Sul materializada através do Projeto, "O RS Biodiversidade", reconhecendo como um fator de contribuição ao desenvolvimento do Rio Grande do Sul e, tendo como uma de suas estratégias produzir instrumentos para aprimorar a gestão. Desse modo, ressalta-se que o bioma da Mata Atlântica é altamente prioritário para a conservação da biodiversidade mundial e que é imprescindível que o município de Santa Maria, por apresentar tais remanescentes, desenvolva políticas e práticas que garantam a conservação desses remanescentes.

\section{Zoneamento ambiental e diretrizes para os planos de manejo}

O Zoneamento ambiental é um dos instrumentos definido na PNMA que tem por finalidade organizar o território, estabelecendo medidas e padrões de proteção ambiental a fim de garantir a qualidade ambiental, isto é, dos recursos hídricos, do solo e da conservação da biodiversidade, possibilitando o desenvolvimento sustentável e a melhoria das condições de vida da população. Segundo o SNUC na Lei no 9.985/2000, o zoneamento é definido como:

definição de setores ou zonas em uma Unidade de Conservação com propósito de proporcionar os meios e as condições para que todos os objetivos da unidade possam ser alcançados de forma harmônica e eficaz. (BRASIL, 2000, n.p.).

Portanto, entende-se que o zoneamento busca organizar e limitar o uso da terra, consistindo na adequação de ações que permitam e busquem o desenvolvimento harmônico do meio ambiente. No entanto, lembra-se que antes do zoneamento ocorrer 
é necessário realizar um diagnóstico ambiental da área a ser analisada a fim de averiguar as potencialidades e fragilidades presentes na mesma para assim comprovar e justificar a proteção de cada espaço afinal, cada unidade de zoneamento possui objetivos e normas a serem considerados.

Já em relação ao plano de manejo, o SNUC na Lei no 9.985/2000, o define como:

documento técnico mediante o qual, com fundamento nos objetivos gerais de uma Unidade de Conservação, se estabelece o seu zoneamento e as normas que devem presidir o uso da área e o manejo dos recursos naturais, inclusive a implantação das estruturas físicas necessárias à gestão da Unidade de Conservação (BRASIL, 2000, n.p.).

Sob essa perspectiva, Bensusan (2006) aponta, que:

\begin{abstract}
a maior razão para justificar a necessidade de manejar os ecossistemas a serem conservados nas áreas protegidas é a dimensão do impacto humano e suas consequências para a nossa espécie. Por toda parte, as atividades humanas comprometeram a capacidade natural regenerativa e autossustentável de vários ecossistemas. Se desejarmos mitigar os efeitos de fenômenos como conversão de áreas naturais, espécies invasoras, ampliação da atuação de patógenos, poluição química e industrial, o manejo é ferramenta fundamental (BENSUSAN, 2006, p. 105).
\end{abstract}

Assim, compreende-se que o plano de manejo tem por finalidade garantir e restaurar a composição, estrutura e função dos ecossistemas. Logo, o plano de manejo é determinado como o principal instrumento de planejamento de uma UC, pois ele define o zoneamento e normas da área para a restrição do uso nesta, visando à conservação (IBAMA, 2002). O mesmo garante que para o cumprimento desses objetivos o planejamento seja contínuo, envolvendo constante aperfeiçoamento visando manter a proposta de manejo atualidade; gradativo, em razão dos constantes desenvolvimentos dos conhecimentos sobre os recursos naturais e culturais da UC; flexível, possibilitando adicionar novos conhecimentos e casuais correções ao plano de manejo durante a implementação de qualquer das fases; e participativo, prevendo o envolvimento da sociedade no processo de planejamento.

Portanto, ressalta-se que a construção do plano de manejo é uma etapa fundamental do planejamento de uma UC. Todavia, superadas essa etapa de elaboração de um plano de manejo para uma UC, não terminam os desafios. Na verdade, pode-se dizer que o maior desafio é executar plano de manejo, fazendo com que as ações estabelecidas se tornem realidade. Afinal, a concretização completa de certa unidade só ocorrerá se o plano de manejo for respeitado, permitindo sua conservação e sua qualidade ambiental. Deste modo, Morsello afirma que o controle e monitoramento das UCs são necessários para garantir que essas não existam apenas no papel:

(...) em países pobres e em desenvolvimento, o manejo é incipiente ou praticamente inexistente, fazendo com que as UCs sejam reconhecidas 
como "parques de papel", ou seja, áreas instituídas legalmente mas que não são submetidas a nenhuma forma de manejo (MORSELLO, 2006, p. 201).

\section{Metodologia}

Primeiramente, foi realizado a definição do marco teórico da investigação e o resgate conceitual de temas abordados e discutidos para assim, consolidar a construção do referencial teórico e conceitual. Entre os temas e conceitos em questão, destacamse: áreas protegidas, UCs, zoneamento ambiental e plano de manejo. Posteriormente, foram realizados trabalhos de campo que tiveram não somente um caráter quantitativo, mas também uma preocupação no levantamento de dados qualitativos. Diante disso, inicialmente foram ouvidos os sujeitos envolvidos com a problemática como, por exemplo, técnicos vinculados ao Iplan, Secretaria de Proteção Ambiental e ao Grupo de Discussão sobre Parques Urbanos e UCs. Nesta etapa também, está à participação nas audiências públicas relacionadas à implantação do Parque do Morro e Parque São Vicente Pallotti.

Os mapeamentos temáticos permitiram a identificação, caracterização e mapeamento das diferentes paisagens e das articulações o que subsidiou a proposta de um zoneamento e, elaboração de diretrizes para o plano de manejo. Para a confecção dos mapas de hipsometria, declividade e de cobertura do solo de ambos os parques, utilizou-se o software ArcGIS 10 (ESRI). Após o estabelecimento do programa a ser utilizado para essa confecção delimitou-se as áreas de estudo, as quais foi adquiridas em formato KMZ via download junto ao site do Iplan. Posteriormente realizou-se a importação desses de limites para o formato Shapefile, foi adicionado sobre os limites dos parques a imagem SRTM (EMBRAPA) referente à região central do RS. Na ferramenta 3D Analyst do ArcGIS, extrairma-se as curvas de nível de 5 em 5 metros. Após a extração das curvas de nível criou-se o modelo digital do terreno (MDT), com as classes altimétricas gerando, portanto os mapas hipsométricos, onde se estabeleceram 5 classes temáticas. Depois, criaram-se os mapas de declividade onde foram definidas também 5 classes temáticas em limites de porcentagem sendo eles (HERZ, R. e DE BIASI, M. 1989):

$><5 \%$ : Determina o limite urbano-industrial;

$>5$-12\%: Estabelece o limite máximo do emprego da mecanização na agricultura;

> 12 - 30\%: É o limite máximo para urbanização sem restrições - Segundo a Lei 6766/79;

> 30 - 47\%: Conforme o Código Floresta, é o limite máximo de corte raso, a partir do qual a exploração só será permitida se sustentada por cobertura de florestas Lei N. ${ }^{\circ} 4771 / 65$ de 15/09/65;

$>>47 \%$ : O artigo 10 do Código Florestal prevê que na faixa situada entre $25^{\circ}$ $(47 \%)$ a $45^{\circ}(100 \%)$, "não é permitida a derrubada de florestas, ...só sendo tolerada a 
extração de toros, quando em regime de utilização racional, que vise a rendimentos permanentes".

Já os mapas de cobertura do solo foram confeccionados através da composição RGB da imagem orbital do satélite Landsat 5, com data de passagem em 13/09/2013. Quanto a esses mapas, estabeleceram-se classes aos distintos tipos de cobertura do solo, isto é: floresta a vegetação que apresente predominância de indivíduos lenhosos, onde as copas das árvores se tocam formando um dossel; vegetação rasteira são áreas que se caracteriza pela presença de uma vegetação rasteira (gramíneas) e pequenos arbustos; solo exposto são as áreas que se caracterizam por não apresentarem ou praticamente não apresentarem qualquer tipo de cobertura; área construída caracterizase pela presença de edificações e padrões de forma regulares e retilíneos ligados ao arruamento; estrada são vias que permitem o tráfego de diversos veículos; e drenagem que são os corpos d'água.

Na sequência procedeu-se, a elaboração de um mapa que apresenta a inserção da RBMA nas áreas de estudo. Esse mapa teve como base a fase VI da Reserva da Biosfera (2008) em formato de arquivo KML n 28 (CNRBMA, 2013) sobreposto com KML da área de estudo no Google Earth disponibilizada pelo Conselho Nacional da RBMA. Já para os mapas de zoneamento ambiental utilizaram-se os resultados obtidos na elaboração dos mapas anteriores e as zonas sugeridas pelo Roteiro Metodológico de Planejamento (IBAMA, 2002) para Parques Nacionais (Quadro 1).

Quadro1: Tipos de zoneamento e normas gerais de manejo das zonas.

\begin{tabular}{|c|c|}
\hline Tipo de Zoneamento & Normas Gerais de Manejo das Zonas \\
\hline $\begin{array}{l}\text { Zona Primitiva: é aquela } \\
\text { onde tenha ocorrido pouca } \\
\text { intervenção humana, tendo } \\
\text { por objetivo preservar o } \\
\text { ambiente natural e facilitar as } \\
\text { atividades de pesquisa } \\
\text { científica e educação } \\
\text { ambiental. }\end{array}$ & $\begin{array}{l}\text { Atividades permitidas: pesquisa científica, fiscalização constante, } \\
\text { monitoramento e o desenvolvimento de atividades de uso público em nível bem } \\
\text { restrito. } \\
\text { folhetos e/ou recursos indiretos, inclusive aqueles oferecidos no centro de visitantes } \\
\text { (ou de vivência). As atividades permitidas não poderão comprometer a integridade } \\
\text { dos recursos naturais. } \\
\text { para não deixarem lixo nessas áreas. } \\
>\text { Não serão permitidas quaisquer instalações de infraestrutura e é } \\
\text { proibido o tráfego de veículos nesta zona, exceto em ocasiões especiais, em casos } \\
\text { de necessidade de proteção da unidade. }\end{array}$ \\
\hline $\begin{array}{l}\text { Zona de Uso Extensivo: } \\
\text { constituída em sua maioria } \\
\text { por áreas naturais, sendo que } \\
\text { o objetivo do manejo é a } \\
\text { manutenção do ambiente } \\
\text { natural com o mínimo de } \\
\text { intervenção humana, mas } \\
\text { com acesso público para fins } \\
\text { educativos e recreativos. }\end{array}$ & $\begin{array}{l}\text { Atividades permitidas: pesquisa, monitoramento ambiental, visitação e } \\
\text { constante fiscalização. } \\
\text { recursos naturais e a recreação, sempre em harmonia com a paisagem e sanitários } \\
\text { nas áreas vocacionais mais distantes do centro de visitantes. } \\
>\text { As atividades de interpretação e recreação terão em conta facilitar a } \\
\text { compreensão e a apreciação dos recursos naturais. } \\
\text { km O trânsito de veículos será feito a baixas velocidades (máximo de } 40 \\
\text { embarcações, não serão permitidos motores abertos e mal regulados. }\end{array}$ \\
\hline
\end{tabular}




\begin{tabular}{|c|c|}
\hline Tipo de Zoneamento & Normas Gerais de Manejo das Zonas \\
\hline $\begin{array}{l}\text { Zona de Uso Intensivo: visa } \\
\text { manter o ambiente o mais } \\
\text { natural possível, mas permite } \\
\text { a construção de } \\
\text { infraestrutura de visitação e } \\
\text { serviços. }\end{array}$ & $\begin{array}{l}\text { O centro de visitantes e outros serviços oferecidos ao público, somente } \\
\text { poderão estar localizados nesta zona. Preferencialmente estas instalações devem } \\
\text { estar localizadas no interior da unidade, para que levem os visitantes a conhecerem } \\
\text { melhor o parque. } \\
\text { lixeiras e trilhas nos locais apropriados. Todas as construções e reformas deverão } \\
\text { estar harmonicamente integradas com o meio ambiente e essa utilização será } \\
\text { subordinada à capacidade de suporte dessa área. } \\
\text { as práticas de conservação da natureza e os materiais para a construção ou a } \\
\text { reforma de quaisquer infraestruturas não poderão ser retirados dos recursos naturais } \\
\text { da unidade. A fiscalização será intensiva nesta zona. } \\
\text { Esta zona poderá comportar sinalização educativa, interpretativa ou } \\
\text { indicativa. O trânsito de veículos será feito a baixas velocidades (máximo de } 40 \\
\text { km) e, o uso de buzinas é proibido. } \\
>\text { Os esgotos deverão receber tratamento para não contaminarem rios, } \\
\text { riachos e nascentes. Esse tratamento deve priorizar tecnologias alternativas de } \\
\text { baixo impacto. E os resíduos sólidos gerados nas infraestruturas previstas deverão } \\
\text { ser acondicionados separadamente, recolhidos periodicamente e depositado em } \\
\text { local destinado para tal. }\end{array}$ \\
\hline $\begin{array}{l}\text { Zona de Recuperação: é } \\
\text { uma zona provisória, onde só } \\
\text { é permitido o uso público } \\
\text { para a educação. São áreas } \\
\text { visivelmente alteradas pela } \\
\text { ação do homem, que têm por } \\
\text { objetivo conter essa } \\
\text { degradação dos recursos ou } \\
\text { restaurar a área. Quando } \\
\text { restauradas, passarão a } \\
\text { integrar outra zona } \\
\text { permanente. }\end{array}$ & $\begin{array}{l}\text { Em caso de conhecimento pouco aprofundado da UC, somente será } \\
\text { permitida a recuperação natural das áreas degradadas. } \\
\text { projeto específico devidamente autorizado pela DIREC. } \\
\text { Nas Na recuperação induzida somente poderão ser usadas espécies nativas, } \\
\text { devendo ser eliminadas as espécies exóticas porventura existentes. Esse trabalho } \\
\text { poderá ser interpretado para o público no centro de visitantes. } \\
>\text { As pesquisas sobre os processos de regeneração natural deverão ser } \\
\text { incentivadas. } \\
>\text { Não serão instaladas infra-estruturas nesta zona, com exceção daquelas } \\
\text { necessárias aos trabalhos de recuperação induzida. Tais instalações serão } \\
\text { provisórias, preferentemente construídas em madeira. Os resíduos sólidos gerados } \\
\text { nestas instalações terão o mesmo tratamento citado nas zonas de uso intensivo e } \\
\text { extensivo. } \\
>\text { O acesso a esta zona será restrito aos pesquisadores e pessoal técnico, } \\
\text { ressalvada a situação de eventuais moradores. }\end{array}$ \\
\hline $\begin{array}{l}\text { Zona de Uso Especial: } \\
\text { contém áreas necessárias à } \\
\text { administração, manutenção e } \\
\text { serviços da UC. Tais } \\
\text { construções não podem ser } \\
\text { conflitantes com o caráter } \\
\text { natural da UC, devendo estar } \\
\text { localizadas, } \\
\text { preferencialmente, em áreas } \\
\text { já com alguma alteração. }\end{array}$ & $\begin{array}{l}\text { É destinada a conter a sede da unidade e a centralização dos seus } \\
\text { serviços não comportando visitação. As instalações desta zona preferentemente } \\
\text { deverão localizar-se na porção periférica da unidade. As construções e reformas } \\
\text { deverão estar em harmonia com o meio ambiente. } \\
\text { funcionários e prestadores de serviços. Os veículos deverão transitar em baixas } \\
\text { velocidades e será proibido o uso de buzinas. fiscalização será permanente nesta } \\
\text { zona. } \\
\text { dos resíduos sólidos gerados na unidade, os quais deverão ser removidos para o } \\
\text { aterro sanitário ou vazadouro público mais próximo, fora da UC. A matéria } \\
\text { orgânica gerada nas UC localizadas em áreas remotas deverá sofrer tratamento } \\
\text { local, exceto queima. E, os esgotos deverão receber tratamento para não } \\
\text { contaminarem rios, riachos e nascentes. Esse tratamento deve priorizar tecnologias } \\
\text { alternativas de baixo impacto. }\end{array}$ \\
\hline $\begin{array}{l}\text { Zona de Amortecimento: é } \\
\text { o entorno da UC, onde as } \\
\text { atividades humanas estão } \\
\text { sujeitas a normas e restrições } \\
\text { específicas. }\end{array}$ & $\begin{array}{l}\text { Não consta. No entanto, as UCs situadas no território do RS sofrem os } \\
\text { efeitos do artigo } 55 \text { do Código Estadual do Meio Ambiente, permanecendo a } \\
\text { exigência de autorização do órgão responsável pela administração da UC para } \\
\text { licenciamentos no raio de } 10 \mathrm{~km} \text { ao redor dos limites da mesma, sem limite de } \\
\text { tempo para validade da norma. }\end{array}$ \\
\hline
\end{tabular}

Fonte: Roteiro Metodológico de Planejamento (IBAMA, 2002).

Organização: Autores. 


\section{Caracterização das áreas de estudo}

Santa Maria localiza-se na região central do estado do RS, na Depressão Periférica Sul-Rio-Grandense (Figura 1). Segundo dados do IBGE (2010), Santa Maria possui $1.788,1 \mathrm{~km}^{2}$ de área total e cerca de 261.031 habitantes, sendo que 95\% dessa população habita a área urbana.

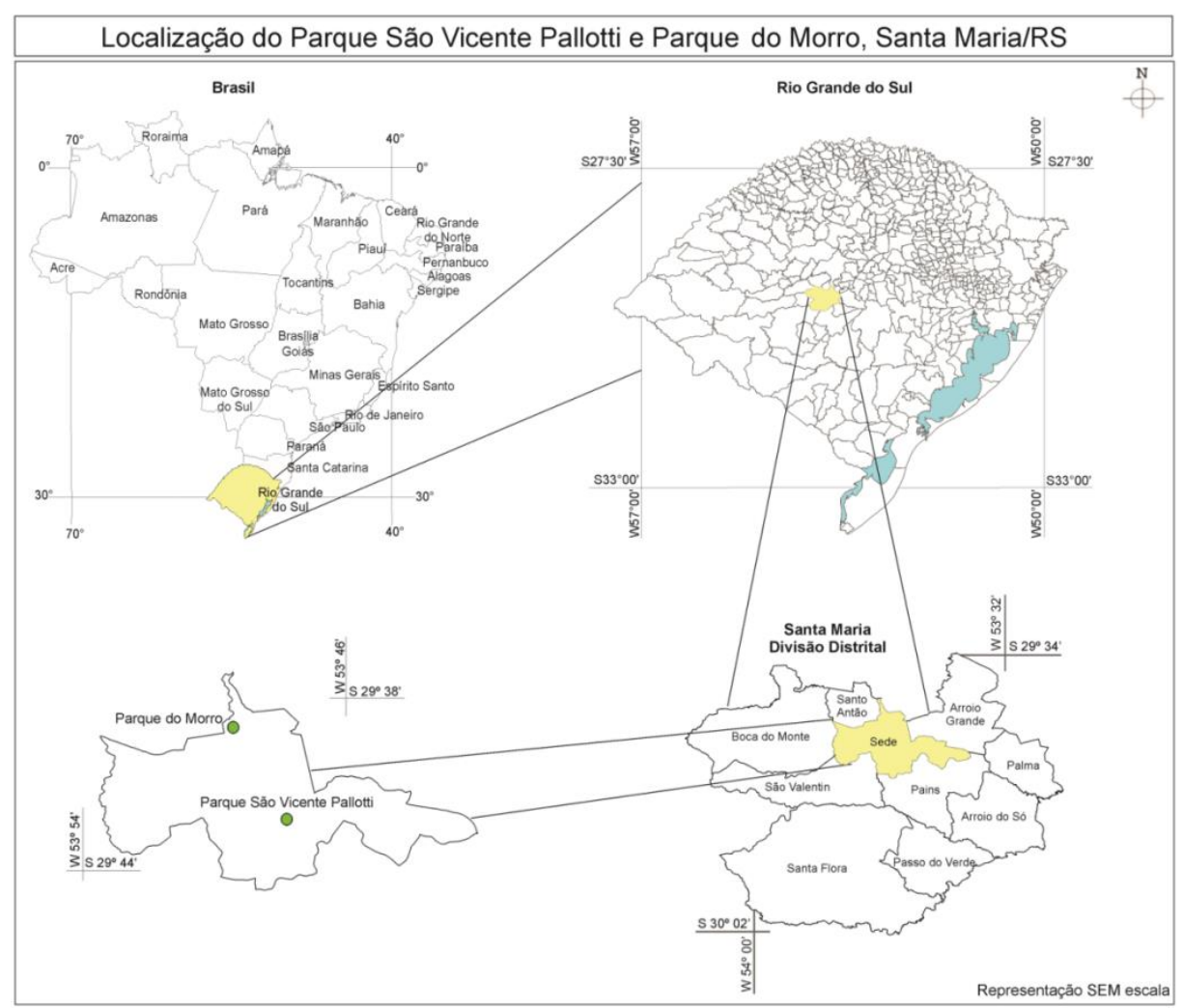

Figura 1 - Mapa de localização do Parque do Morro e do Parque São Vicente Pallotti, Santa Maria/RS. Fonte: elaborado pelos autores (2014).

Quanto ao clima, Heldwein, Buriol e Streck (2009) definem que, com base na classificação de Köppen, o clima da região é subtropical úmido, ou seja, com verões quentes e sem estação seca definida. Já a pedologia de Santa Maria, conforme Dalmolin e Pedron (2009), tem por característica diferentes tipos de solos, possibilitando assim diversos tipos de usos. Entre esses solos, os autores afirmam que os mais significativos na região são os argissolos, planossolos, gleissolos e neossolos.

Geomorfologicamente, Santa Maria é conhecida por ser uma área de transição entre a Depressão Central do RS e a Escarpa Erosiva do Planalto Meridional Brasileiro, 
ou seja, a áreas mais elevadas se encontram a porção norte da cidade, enquanto que na porção sul situam-se as áreas com menores declives e altitudes. Paralelamente a isso, destaca-se a presença do bioma Mata Atlântica nas porções norte e leste e, do bioma Pampa nas porções sul e oeste do distrito sede.

A área de estudo referente ao Parque São Vicente Pallotti corresponde a uma superfície de terras com aproximadamente 17 hectares (ha), localizada na zona urbana, entre os bairros Nossa Senhora das Dores e Nossa Senhora de Lourdes. Todavia, ressalta-se que desses 17 ha o município de Santa Maria recebeu, através da Lei Municipal $n^{\circ} 5329 / 10$, áreas em doação, totalizando 6,323 ha, ou seja, as demais áreas imediatamente contíguas à área doada são de interesse do município para a ampliação para esse Parque.

Com relação ao Parque do Morro, destaca-se que a área do mesmo satisfaz a uma superfície de terras com aproximadamente 156 ha localizada em sua maior parte no bairro Nossa Senhora do Perpétuo Socorro, e uma pequena fração no distrito de Santo Antão.

Logo, ao observamos a atual situação em que se encontram essas áreas dos Parques, nota-se que essas sofrem pressões referentes à expansão urbana e, consequentemente da especulação imobiliária. Assim, subentende-se que se não houve alguma atitude para conter tais avanços e pressões sobre essas áreas dos Parques, provavelmente essas ficaram vulneráveis a impactos ambientais. Fato essa que salienta a necessidade e importância de instituir dessas UCs.

Sobretudo, ao verificar-se a legislação ambiental de Santa Maria encontram-se aspectos relevantes voltados a áreas protegidas no Plano Diretor de Desenvolvimento Urbano Ambiental de Santa Maria, Lei no 034/2005, que, segundo seu Art. $1^{\circ}$, tem por finalidade ordenar o desenvolvimento das funções sociais da cidade e do meio rural, garantindo o bem-estar de seus habitantes. Ainda de acordo com o plano encontram-se políticas públicas importantes que têm contribuindo na sistematização do planejamento ambiental da cidade e em especial, entre elas destacam-se: premissas de sustentabilidade, políticas de manejo dos recursos naturais urbanos e políticas municipais de manejo sustentável da área de influência da RBMA. Todavia, observa-se que na prática estas leis estão sendo pouco efetivas.

Sob esse plano destaca-se ainda que o mesmo dispõe de políticas, programas e projetos ambientais para Santa Maria que poderiam ser mais aproveitados, divulgados e até mesmo discutido com a sociedade como, por exemplo, o reconhecimento do município como "Portal Sul da RBMA, com serviços e equipamentos para o ecoturismo. (SANTA MARIA, 2005). Diante dessa legislação ambiental, é possível depara-se com a delimitação das Áreas Especiais Naturais, que são definidas e delimitadas no Anexo 12 da Lei de Uso e Ocupação do Solo, Parcelamento, Perímetro Urbano e Sistema Viário de Santa Maria/Luos (nº 072/2009). Estas áreas são dividas em “Áreas Especiais de Conservação Natural, particulares ou públicas”, em seu 
primeiro parágrafo e em “Áreas Especiais de Preservação Permanente”, no segundo parágrafo. Todavia, observa-se que não existe qualquer referência sobre as áreas aqui estudadas.

\section{Resultados e discussões}

No levantamento hipsométrico realizado na área já destinada ao Parque São Vicente Pallotti (Figura 2) aponta uma amplitude altimétrica de aproximadamente 216 metros. Já, ao considerar-se também a área de interesse da prefeitura para esse Parque essa amplitude muda para 288 metros.

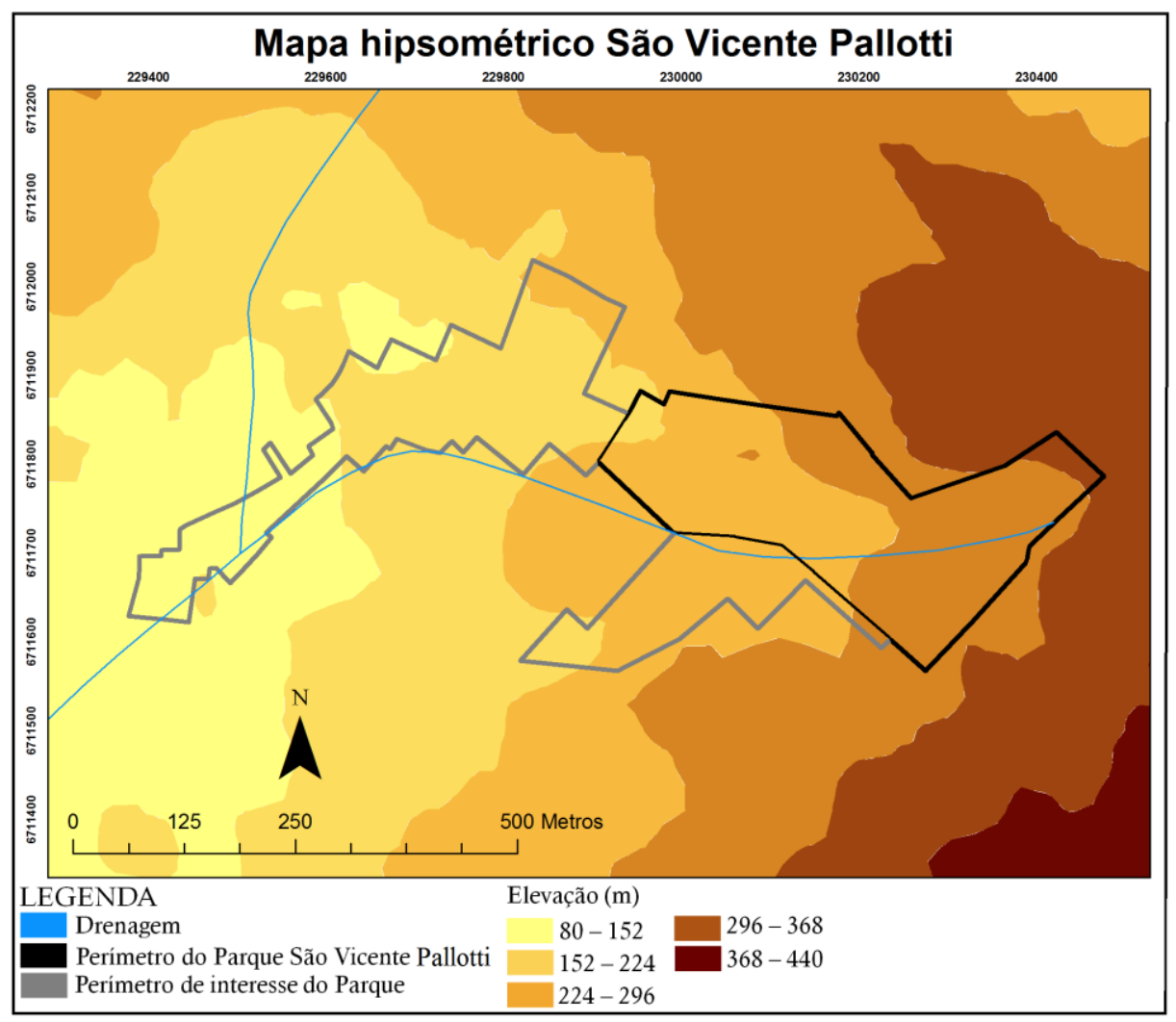

Figura 2 - Mapa hipsométrico do Parque São Vicente Pallotti - Santa Maria/RS. Fonte: elaborado pelos autores (2014).

Deste modo, percebe-se no mapeamento o gradativo aumento da altitude em direção leste da área de estudo. Outro fato importante observado neste mapa é que toda a área do Parque apresenta altitude acima de 100 metros. Consequentemente, ressaltase que tanto a área do Parque São Vicente Pallotti (Figura 2) quanto do Parque do 
Morro (Figura 3) está na RBMA, pois no município de Santa Maria, as áreas acima de 100 m de altitude são consideradas pertencentes à RBMA.

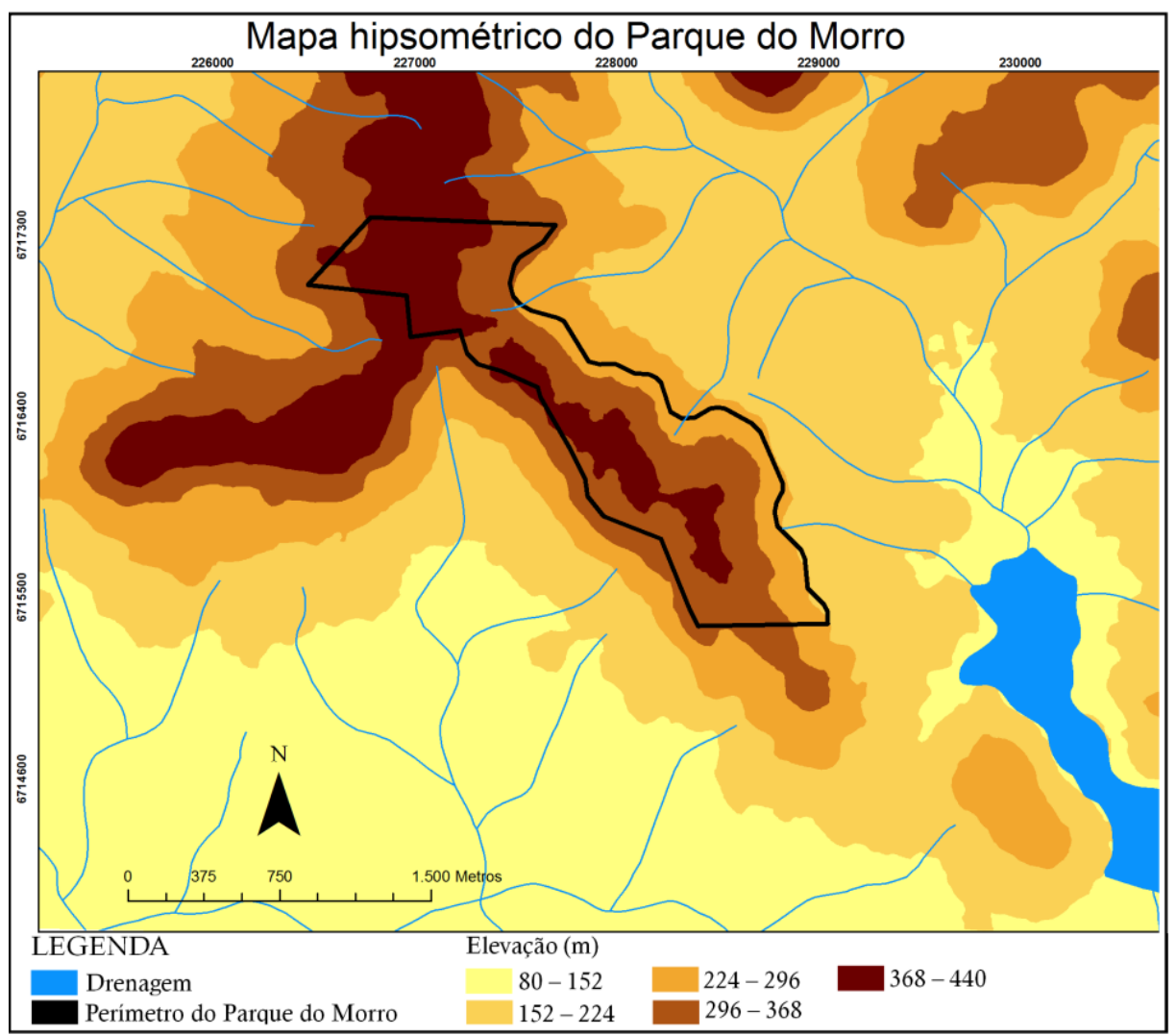

Figura 3 - Mapa hipsométrico do Parque do Morro - Santa Maria/RS.

Fonte: elaborado pelos autores (2014).

No levantamento hipsométrico efetivado na área do Parque do Morro (Figura 3) verificou-se uma amplitude altimétrica de aproximadamente 288 metros e paralelamente a isso, nota-se o gradativo aumento da altitude em direção oeste e noroeste, passando pelo norte da área de estudo, apontando assim o aumento na inclinação do relevo, fato esse que pode ser associado em virtude dessa região estar situada na escarpa do Planalto Meridional Brasileiro.

A partir da elaboração do mapa de declividade do Parque São Vicente Pallotti (Figura 5), o qual possibilita expressar as inclinações do relevo juntamente com outras variáveis, é possível caracterizá-la como uma região com relevo levemente ondulado por apresentar justamente pouca variação de declividade, isto é, entre 0 e $5 \%$. Nota-se 
ainda que tanto a área do Parque quanto a de interesse e de entorno não apresentam declividades maiores de $30 \%$.

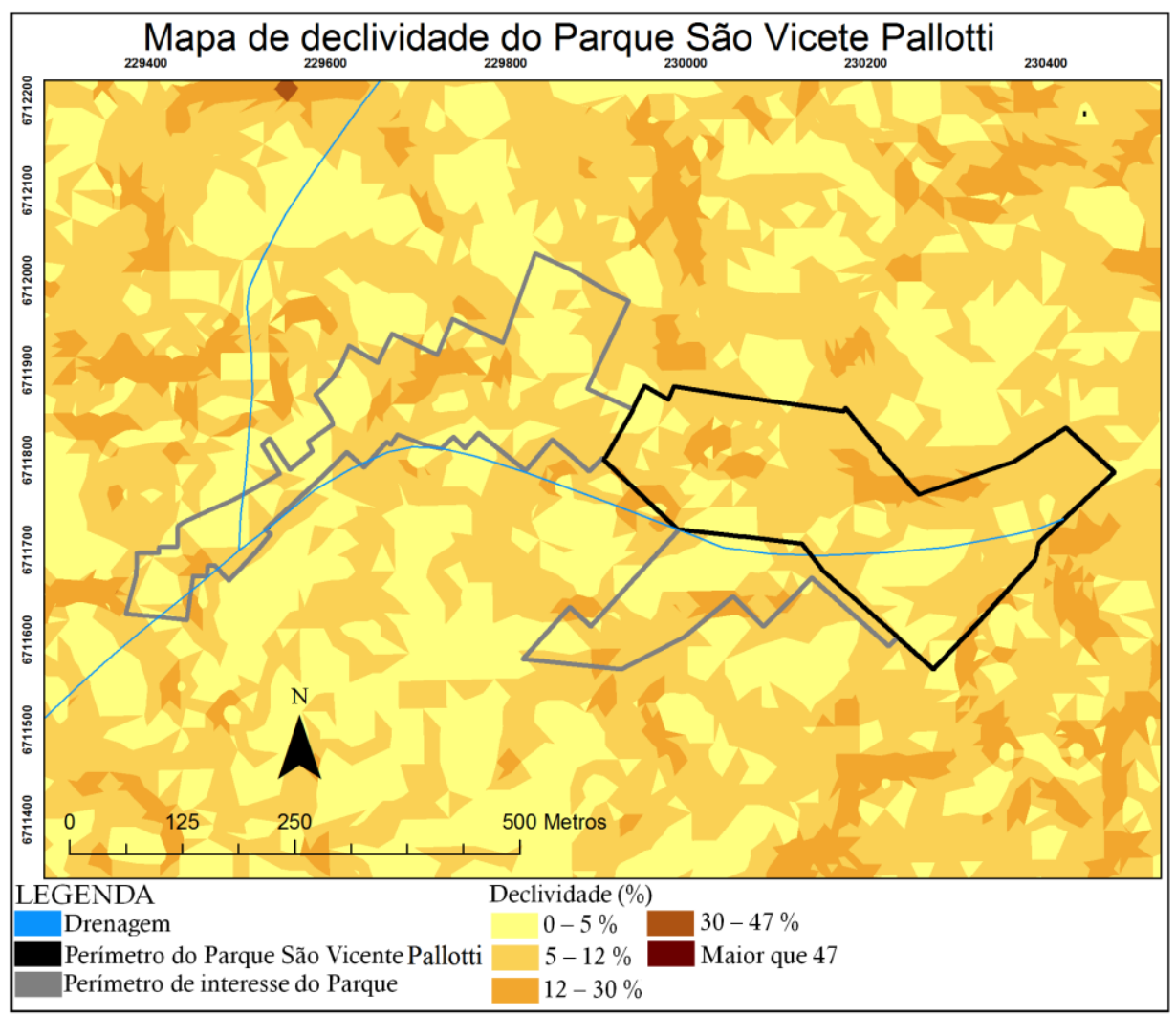

Figura 4 - Mapa de declividade do Parque São Vicente Pallotti - Santa Maria/RS.

Fonte: elaborado pelos autores (2014).

Já, diante do mapa de declividade do Parque do Morro (Figura 4) percebe-se que as variações das declividades são mais expressivas, caracterizando a região com relevo acentuado e, com a possível identificação de APPs, as quais consistem na restrição de uso e ocupação. 


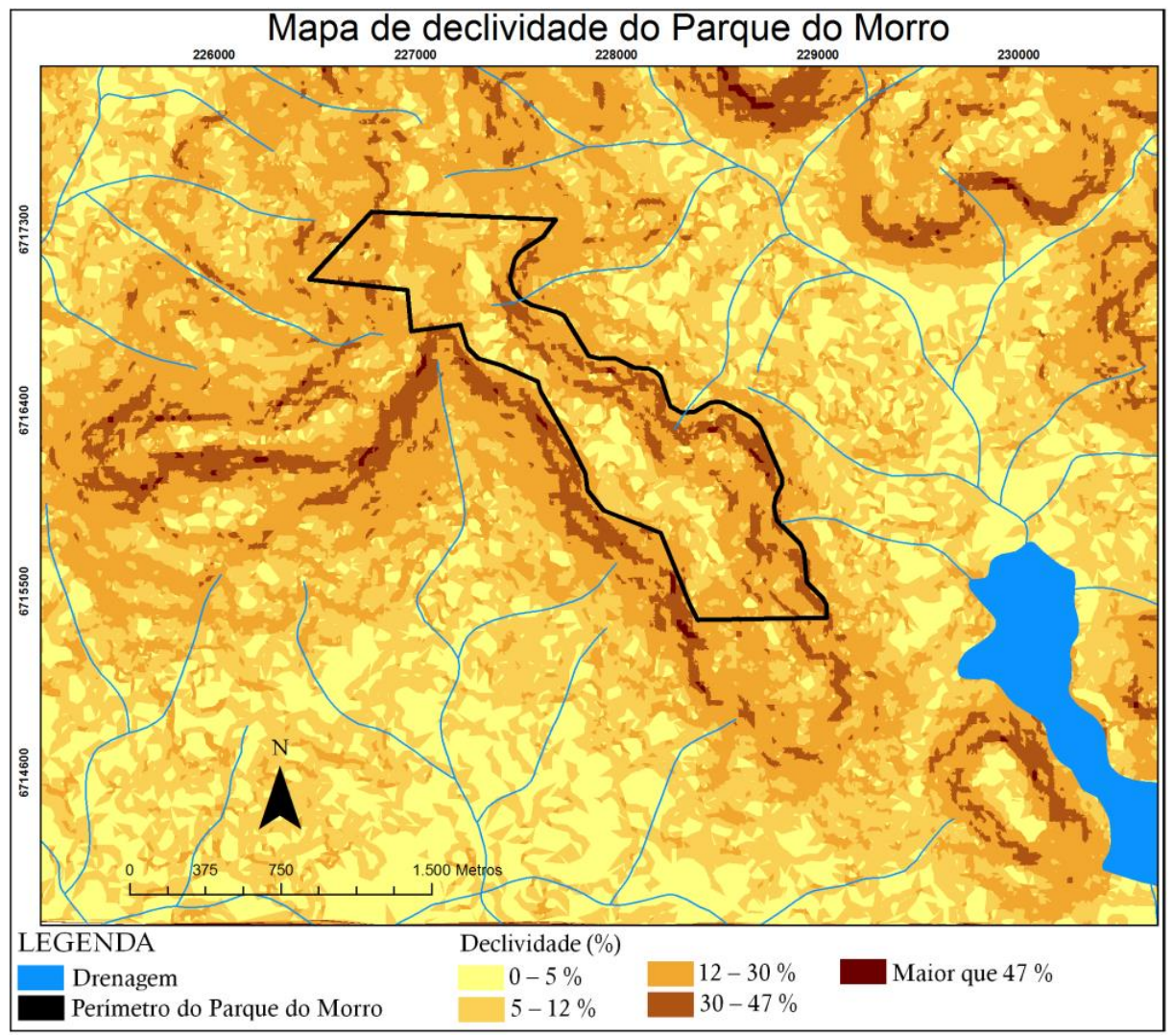

Figura 5 - Mapa de declividade do Parque do Morro - Santa Maria/RS.

Fonte: elaborado pelos autores (2014).

No mapa de cobertura vegetal do Parque São Vicente Pallotti (Figura 6), notase que na área já consolidada a esse Parque encontra-se, na sua grande maioria, ocupada por floresta e em seguida, em menor expressão, por vegetação rasteira. Entretanto, ao analisar-se o perímetro de interesse da prefeitura para esse Parque, observa-se que o uso é bem mais amplo do que na área já definida para esse Parque, isto é, além de apresentar a presença de floresta e vegetação rasteira, apresenta ainda a presença de solo exposto, área construída e estradas. Assim, destaca-se o fato da inviabilidade de incorporar, em sua totalidade, essas áreas que já foram edificadas e antropizadas. 


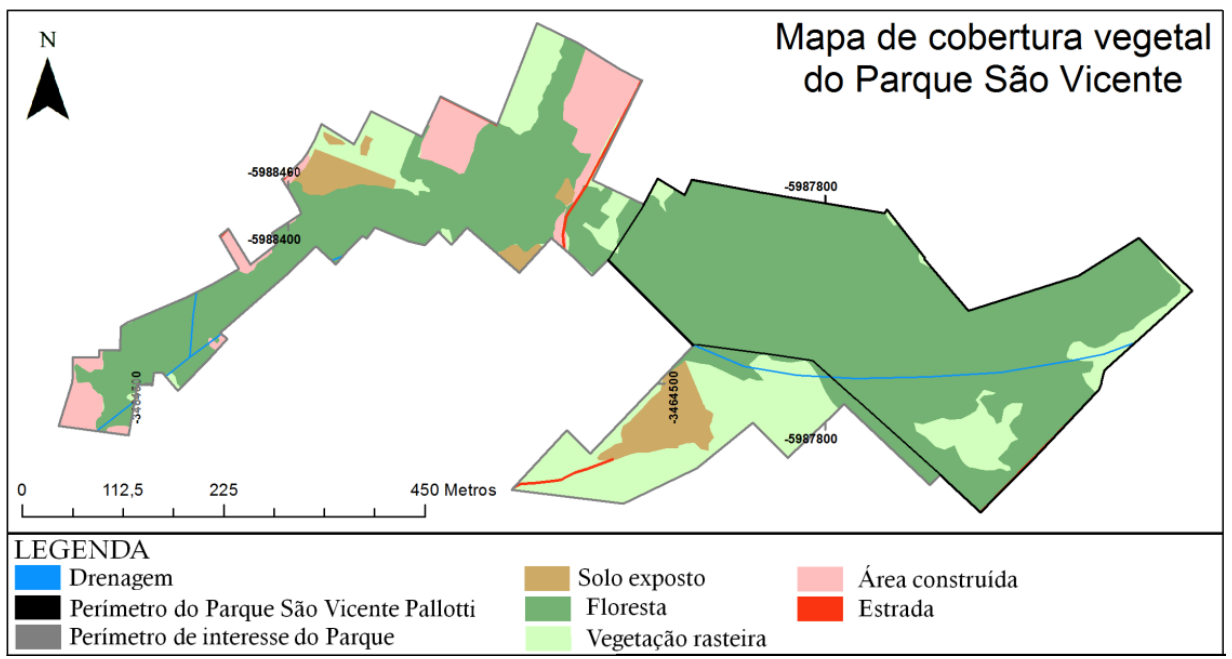

Figura 6 - Mapa de cobertura vegetal do Parque São Vicente Pallotti - Santa

Maria/RS. Fonte: elaborado pelos autores (2014).

Diante do mapa de cobertura do solo do Parque do Morro (Figura 7) é possível perceber que no decorrer da área estudada ocorrem somente à presença vegetação rasteira e de floresta, a qual se encontra na grande maioria. Em relação a esse resultado, pode-se apontar que o mesmo ocorre, possivelmente, em razão de essa área situar-se no Rebordo do Planalto Meridional Brasileiro e ter sido praticamente isolada de usos agressivos e intensivos, possibilitando a mesma a desenvolver sua capacidade de resiliência buscando assim, reestabelecer o seu ecossistema mais natural possível. Sob esse resultado, destaca-se ainda que o mesmo só fora possível graça a comparação de imagens de satélites com datas anteriores a utilizada para a elaboração desse mapa e de estudos que comprovam tais transformações sobre essa área e seus entorno. 


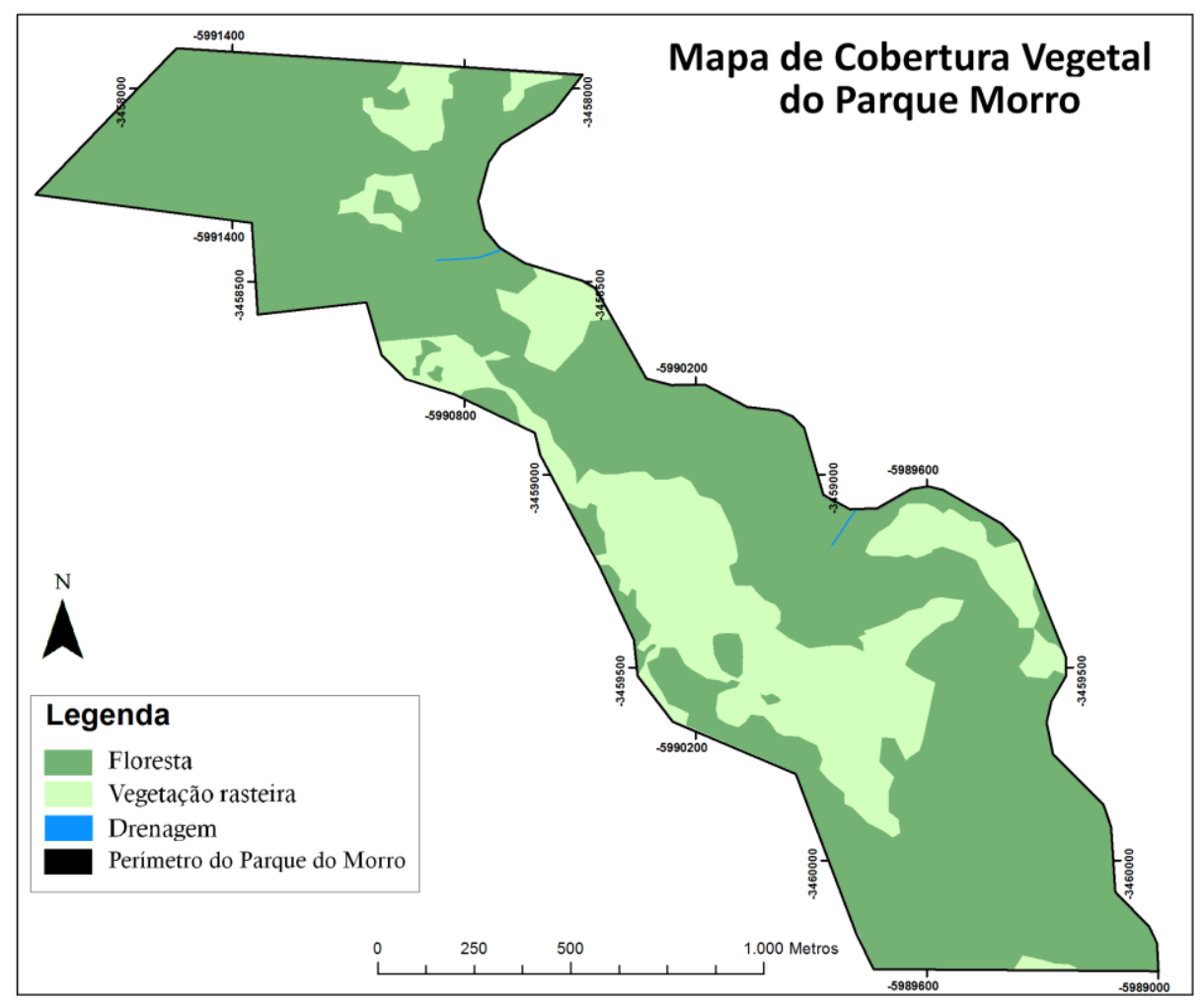

Figura 7 - Mapa de cobertura vegetal do Parque do Morro - Santa Maria/RS. Fonte: elaborado pelos autores (2014).

Vale ressaltar também que o Parque dos Morros constitui um importante fragmento da topografia local com significativo interesse ecológico, tanto do ponto de vista da formação vegetal quanto da diversidade biológica, fato que justifica a criação do parque. Além disso, destaca-se ainda que em razão do Parque do Morro apresentar tais características o torno atraente para atividades turísticas em razão de apresentar belas paisagens da região, desde o seu topo e arredores às áreas mais periféricas onde se localiza o centro da cidade de Santa Maria (Figura 8). 


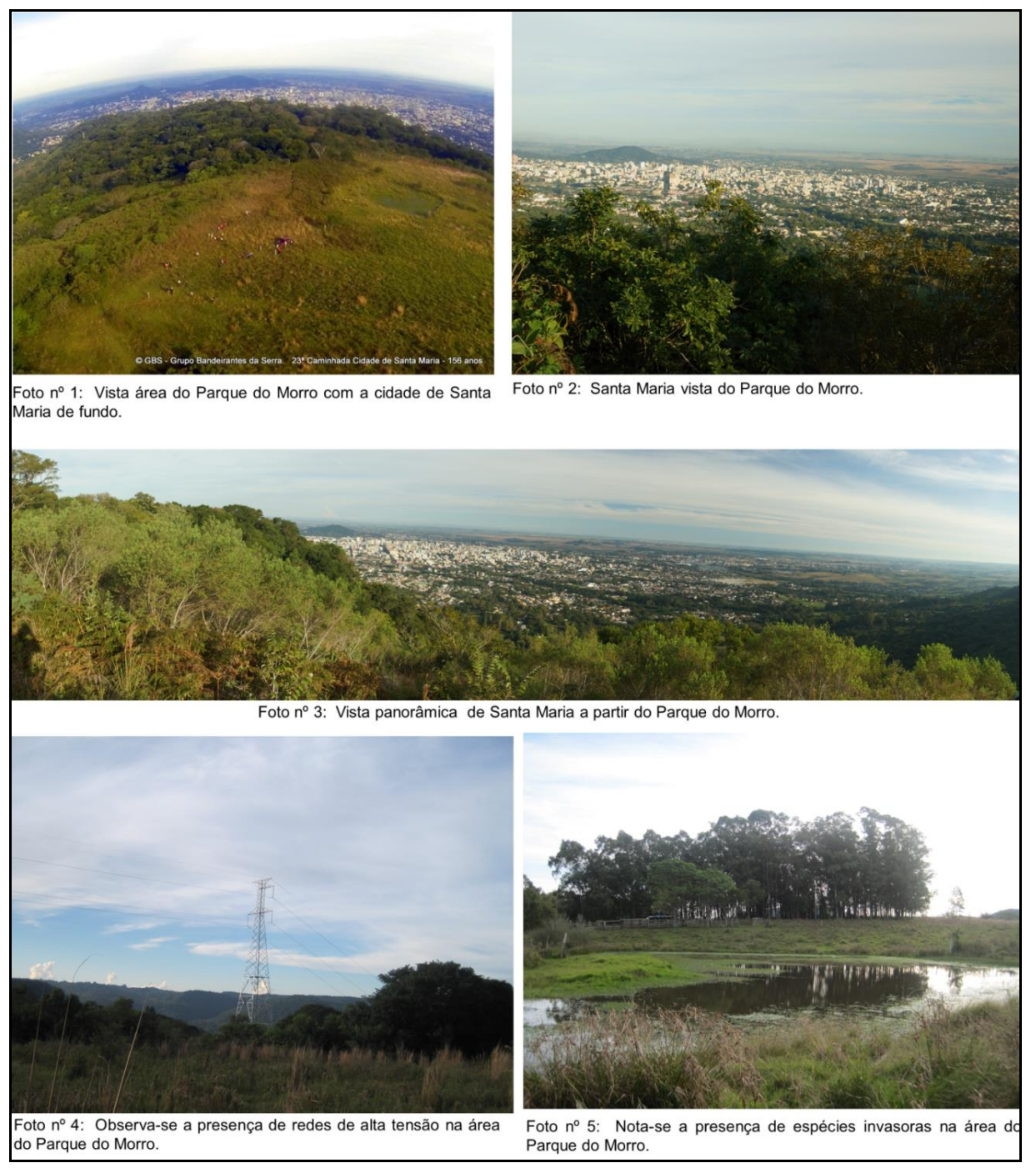

Figura 8 - Fotos do Parque do Morro. Organização: Autores.

Como complemento, ressalta-se que atualmente o Grupo Bandeirante da Serra (GBS) tem a permissão de uso do Parque do Morro possibilitando ao mesmo a efetivação de atividades ecoturísticas, eventos socioambiental e esportivo com o mínimo impacto e ética de seus associados e pessoas tuteladas.

No mapa a seguir da RBMA (Figura 9) nota-se que tanto a área de interesse quando a definida ao Parque São Vicente Pallotti encontram-se na zona de transição e, a área do Parque do Morro, localiza-se, predominantemente como zona núcleo, 
conglobando as porções noroeste, norte e leste, e zona de amortecimento na parte sul e sudoeste no rebordo do planalto na área da cidade.

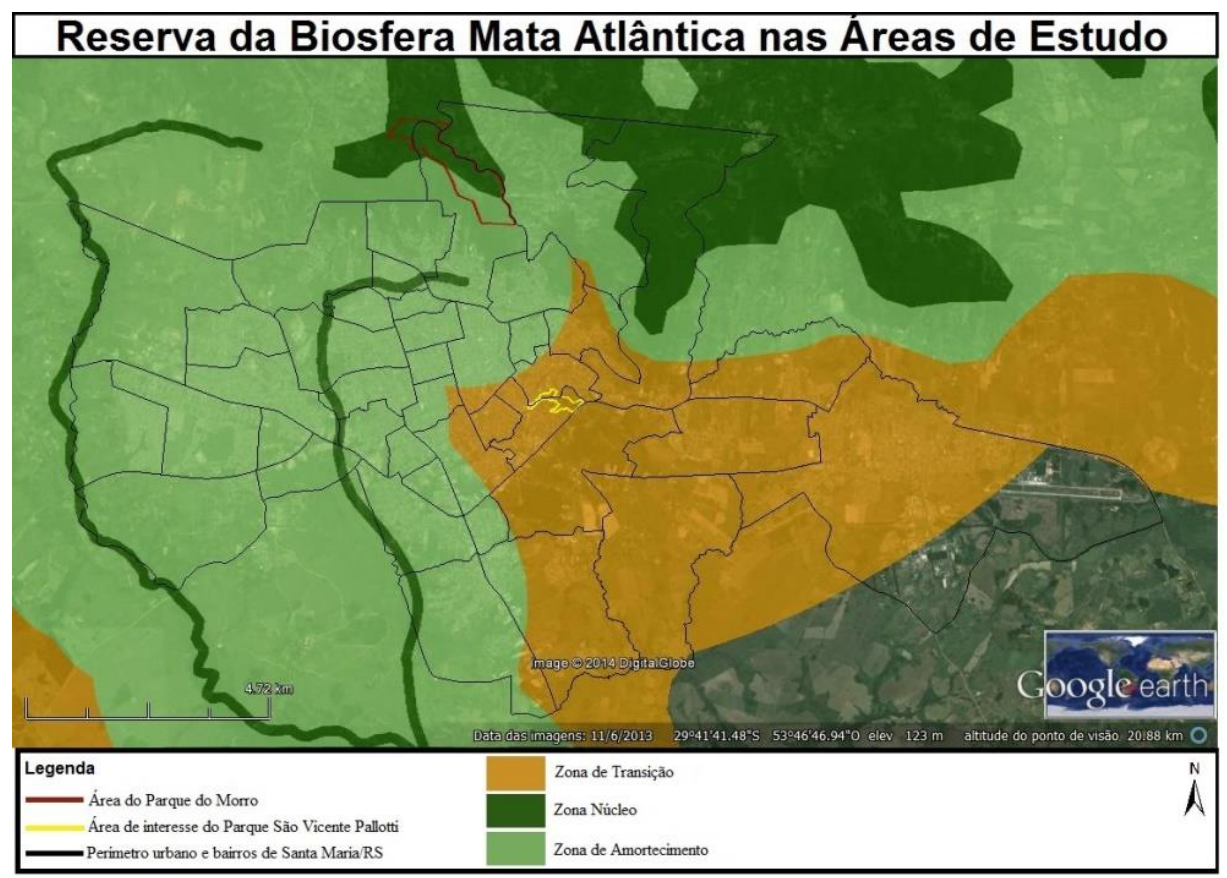

Figura 9: Fase VI da Reserva da Biosfera (2008) incluída nas áreas de estudo. Fonte: Arquivo kml. no 28 (CNRBMA, 2013) disponibilizada pelo Conselho Nacional da RBMA.

Diante desse mapa, busca-se ratificar a importância da instituição de UCs pelo fato dessas áreas dos Parques fazerem partes da RBMA e por essas regiões de transição e amortecimento serem as que mais sofrem pela pressão imobiliária atual no presente município, havendo assim, paulatinamente retirada de exemplares de mata atlântica para construções.

Em seguida, nota-se que no mapa de Zoneamento Ambiental do Parque São Vicente Pallotti (figuras 10) apresentam-se apenas três tipos de zonas. Esse fato se justifica, principalmente pelo tamanho da área do Parque, que é relativamente pequena se comparada à área de interesse para com esse parque e demais Parque Nacionais. Todavia, ratifica-se a importância desta área ser de posse do poder público e do potencial que a mesma tem, em razão de suas peculiaridades e de despertar o interesse de agentes sociais do entorno da mesma para a conservação de áreas como essa. 


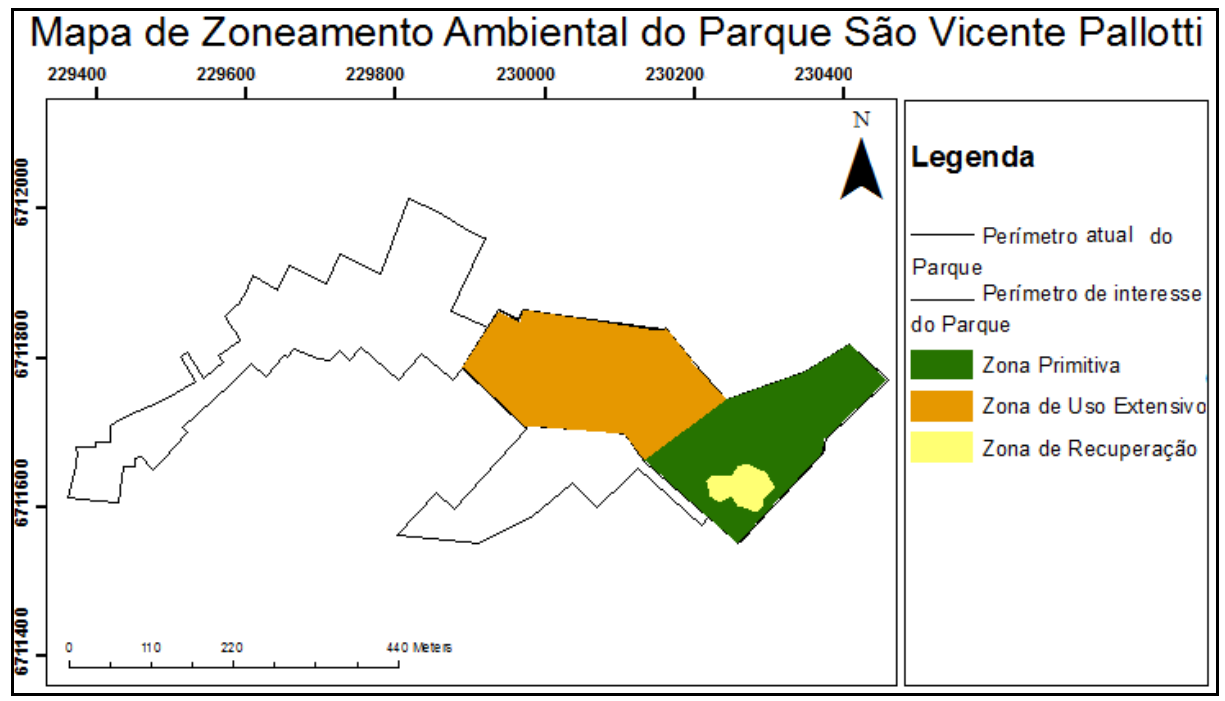

Figura 10: Mapa de Zoneamento Ambiental do Parque São Vicente Pallotti. Fonte: elaborado pelos autores (2014).

Ainda sobre esse mapa (Figura 10) salienta-se, em sua maioria, a zona de uso extensivo, a qual é formada predominantemente por áreas naturais com significativos remanescentes de Mata Atlântica que possibilita acesso público para fins educativos e recreativos com o mínimo de intervenção humana. Nota-se que a zona primitiva apresenta também expressivos remanescentes de Mata Atlântica, no entanto de forma menos expressiva a zona anterior, pois apresenta uma clareira no meio da mata, a qual pode estar associada a algum tipo de exploração indevida para o ambiente ali presente. Logo, subentende-se que essa área deve ser mais restrita, permitindo, basicamente, atividades direcionadas a pesquisa científica, a fiscalização, o monitoramento e o desenvolvimento de atividades de uso público, a fim de assegurar até mesmo a garantia da manutenção da zona de recuperação que é envolvida pela zona primitiva.

Já, no mapa de Zoneamento Ambiental do Parque do Morro (figura 11), observa-se a presença cinco zonas com diferentes normas e manejos. Entre essas zonas a mais abrangente é a zona primitiva, localizada tanto nas áreas mais preservadas e de zona núcleo da RBMA do parque quanto nas áreas mais elevadas e com declividades mais acentuadas. Já zona intensiva foi delimitada na porção que abrange uma antiga estrada de acesso ao topo do morro, ou seja, vai desde a base ao topo do morro. Essa delimitação só foi possível graças às saídas a campo que possibilitaram conhecer melhor a área do parque bem como a sua atual situação.

A zona de uso especial é o espaço com menor abrangência, pois se entende que em razão do Parque localizar-se próximo ao centro urbano e das sedes administrativas municipais, essa zona não necessita de grandes infraestruturas de administração, manutenção e serviços da UC, apesar de que essa zona localiza-se em 
um espaço que já possui alguma alteração. Sob essa realidade, nota-se ainda que a áreas a serem recuperadas em virtude de sua degradação é, também, bastante expressiva e necessita de uma atenção especial, pois se encontram em áreas núcleo da RBMA e com declividades e elevações expressivas, aspectos esses que foram significativos para a delimitação dessa área como tal.

Observa-se também que a zona de uso extensivo localiza-se na porção leste do parque. Ela se constitui predominantemente por áreas naturais, mas com a presença de algumas espécies exóticas, as quais devem ser estudadas e controladas para não haver conflito com as demais espécies nativas dessa área afinal, se estas espécies exóticas forem polinizadas e semeadas, podem tornar-se espécie-praga, prejudicando a conservação da biodiversidade ali presente, e até mesmo à extinção local de espécies.

Sobre esse espaço, destaca-se ainda a possibilidade de instalar equipamentos simples para a interpretação dos recursos naturais e a recreação, em harmonia com a paisagem como, por exemplo, trilhas e de mirantes interpretativos que desfrutem das paisagens que o Parque proporciona. Sob essa perspectiva, lembra-se que tanto as trilhas quanto os mirantes devem ser utilizados sempre de forma segura, organizada e consciente, preservando o ecossistema local e respeitando a capacidade de carga de cada trilha a ser implantada uma vez que a visitação pública é garantida desde que de forma regulamentada e com o mínimo impacto ambiental.

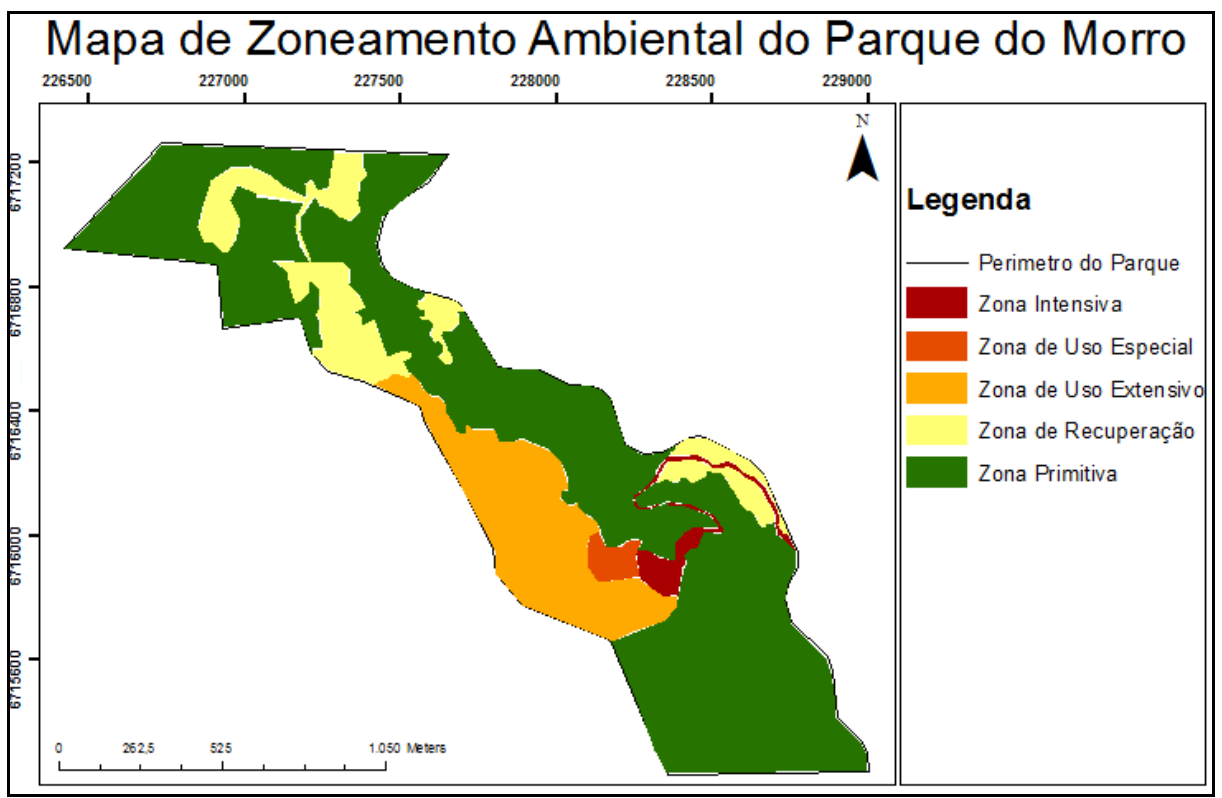

Figura 11: Mapa de Zoneamento Ambiental do Parque do Morro.

Fonte: elaborado pelos autores (2014). 
Cabe destacar ainda sobre a importância de programas direcionados a Educação Ambiental que é dos principais instrumentos de conscientização da importância preservação da fauna e flora e dos ecossistemas existentes. Esse programa além de envolver os visitantes dos Parques deve estar direcionado também na tentativa de envolver principalmente as comunidades existentes entorno das UCs buscando assim despertar o sentimento de valorização ambiental e pertencimento dos mesmos com essa área incentivando-o a ajudarem na conservação, fiscalização e disseminação de ideias sustentáveis.

Outro aspecto que deve ser ressaltado é em relação à divulgação dos Parques através de material informativos e didático como, por exemplo, folders, painéis, livretos, vídeos, etc. Publicações essas que deverão conter informações relacionadas à UC e sua importância, tanto por aspectos de fauna e flora quanto dos benefícios gerados pelas mesmas através da prestação de serviços ambientais, os quais são fundamentais para a qualidade de vida de população.

Já, em relação à vigilância, patrulhamento e a fiscalização nas UCs salienta-se a Lei Estadual 12.583, de 25 de agosto de 2006, que estabelece o cargo de guardaparque. Entre as atribuições deste cargo destacam-se: exercer vigilância nas UCs do Estado do RS sob sua guarda, percorrendo a propriedade ou observando-a do alto de uma torre, para localizar incêndios e descobrir irregularidades, como presença de estranhos, caça e outras práticas danosas; comunicar a administração sobre ocorrência de incêndios e demais irregularidades, bem como do estado das UCs, utilizando rádio, telefone, relatos periódicos e outros meios, para ensejar a tomada de medidas oportunas; orientar o público, acompanhar visitantes e pesquisadores; entre outras. Outros cargos importantes necessários para o manejo e gestão de uma UC são:

- Técnico Ambiental: com a função de executar trabalhos relacionados com atividades referentes à conservação ambiental, coordenação, fiscalização e controle de serviços contratados nas suas diversas fases de desenvolvimento.

- Agente Administrativo: responsável por desenvolve trabalhos direcionado a aplicação da legislação de pessoal, material e de organização administrativa.

Por fim, destaca-se a proposta de Nascimento e Foleto (2010) que aborda sobre a implantação da área de Proteção Ambiental (APA) do Vacacaí-Mirim bem como sua delimitação e zoneamento desta com base na RBMA. A criação desta APA, além de possibilitar a conservação e diversidade biológica dessa área, na qual se inclui o Parque do Morro, serviria como zona de amortecimento para esse Parque auxiliando o comitê gestor e na imposição de restrições no entorno dessas áreas bem como na proteção ambiental. Afinal, com essa APA o processo de ocupação será categórico, assegurando a sustentabilidade dos recursos naturais e permitindo o desenvolvimento de um manejo sustentável. 


\section{Considerações finais}

Entende-se que dentre as estratégias para conservar a natureza, a criação e implantação de uma UCs é uma das mais eficientes afinal, são áreas criadas por lei, especialmente protegidas e administradas para fins de conservação da natureza. Assim, acredita-se que a implantação e a efetivação de UCs nas áreas destinadas ao Parque do Morro e do Parque São Vicente Pallotti seja determinante para a conservação da paisagem natural e dos remanescentes de Mata Atlântica em Santa Maria/RS. Afinal, em razão de essas áreas localizarem-se quase que totalmente no perímetro urbano de Santa Maria elas sofrem corriqueiramente fortes pressões em relação à expansão urbana e especulação imobiliária.

Desse modo, ratifica-se a importância da proposta de implantação dessas UCs, tendo em vista conter esses avanços e conservar os exemplares de Mata Atlântica ali presente, os quais são de extrema relevância em se tratando de conservação da biodiversidade de Santa Maria.

Enfatiza-se ainda da importância de estudos biológicos nas extensões das áreas dos Parques e de seu entorno, visando identificar os componentes bióticos e abióticos existentes nessa área contribuindo assim para a qualificação desse estudo, pois possibilitaria a identificação de áreas propícias a maiores restrições ou não em razão da presença de tais componentes.

Espera-se ainda que através deste trabalho e de outros relacionados à conservação dessas e demais áreas que necessitam tal conservação, despertar o interesse da população, em especial da população que reside em torno das áreas dos parques para que essas compreendam melhor a importância da conservação das mesmas e atuem juntamente com o Poder Público no processo de comunicação e fiscalização ambiental das mesmas.

\section{Referências bibliográficas}

BENSUSAN, N. Conservação da biodiversidade em áreas protegidas. Rio de Janeiro: FGV, 2006.

BRASIL. Lei n. 9.985, de 18 de julho de 2000. Regulamenta o art. 225, $\S 1^{\circ}$, incisos I, II, III e VII da Constituição Federal, institui o Sistema Nacional de Unidades de Conservação da Natureza e dá outras providências. Brasília, 2000. Disponível em: <http://www.planalto.gov.br/ccivil_03/leis/L9985.htm>. Acesso: 6 set. 2012.

. Lei Federal n. 6.938 de 31 de agosto de 1981. Dispõe sobre a Política Nacional do Meio Ambiente, seus fins e mecanismos de formulação e aplicação, e dá outras providências. Presidência da República - Casa Civil, Brasília, DF, 31 ago. 1981. Disponível em: <http://www.planalto.gov.br/ccivil_03/Leis/L6938.htm>. Acesso em: 9 nov. 2012. 
CABRAL, N. R. A. J.; SOUZA, M. P. Área de Proteção Ambiental: Planejamento e gestão de paisagens protegidas. $2 \mathrm{Ed}$. São Carlos: RiMa, 2005.

CONSELHO NACIONAL RESERVA DA BIOSFERA DA MATA ATLÂNTICA. Reserva da Biosfera da Mata Atlântica Fase VI/2008: revisão e atualização dos limites e zoneamento da Reserva da Biosfera da Mata Atlântica em base cartográfica digitalizada. São Paulo: Conselho Nacional da Reserva da Biosfera da Mata Atlântica, 2008. 127 p. Disponível em: <http://www.rbma.org.br/rbma/rbma_fase_vi.asp> Acesso em: 09 ago. 2013.

CORRÊA, F. A Reserva da Biosfera da Mata Atlântica: roteiro para o entendimento de seus objetivos e seu sistema de gestão. São Paulo: UNESCO, 1995. Disponível em: <www.rbma.org.br/rbma/pdf/Caderno_02.pdf> Acesso em: 10 set. 2012.

CNRBMA. Reserva da Biosfera da Mata Atlântica. In: CONSELHO Nacional Reserva da Biosfera da Mata Atlântica. São Paulo: CNRBMA, c2013. Disponível em: < http://www.rbma.org.br/rbma/rbma_fase_vi_03_google.asp>. Acesso em 08 jul. 2014.

DALMOLIN, R. S. D.; PEDRON, F. A. Solos do município de Santa Maria. Ciência \& Ambiente, Santa Maria, n. 38, p. 59-78, jan./jun. 2009.

DE BIASE, M. A carta clinográfica: os métodos de representação e sua confecção. RDG Revista do Departamento de Geografia - USP, São Paulo, v. 6, p. 45-60, 1992.

HELDWEIN, A. B.; BURIOL, G. A.; STRECK, N. A. O clima de Santa Maria. Ciência \& Ambiente, Santa Maria, n. 38, p. 43-58, jan./jun. 2009.

INSTITUTO BRASILEIRO DE GEOGRAFIA E ESTATÍSTICA. IBGE. Sinopse do Censo Demográfico 2010, Rio Grande do Sul. 2010. Disponível em: $<$ http://www.censo2010.ibge.gov.br/sinopse/index.php?dados=21\&uf=43>. Acesso em: 3 set. 2012.

LOBODA, C. R.; DE ANGELIS, B. L. D. Áreas verdes públicas: Conceitos, usos e funções. Ambiência. v.1, n.1. Guarapuava, jan./jun. 2005.

MINISTÉRIO DO MEIO AMBIENTE- MMA. Avaliação e ações prioritárias para a conservação da biodiversidade da Mata Atlântica e Campos Sulinos. Brasília, DF: MMA/SBF, 2000. 40 p. Disponível em: <www.conservation.org.br/publicacoes/files/Sumario.pdf> Acesso em: 12 ag. 2013.

. Biomas - Mata Atlântica. 2012. Disponível em:

<http://www.mma.gov.br/biomas/mata-atlantica>. Acesso em: 7 set. 2012.

. Conselho Nacional do Meio Ambiente (Conama). Resolução no 428, de 17 de dezembro de 2010. Brasília, 2010. Disponível em: 
<http://www.mma.gov.br/port/conama/legiabre.cfm?codlegi=641>. Acesso em: 19 de jun. 2013.

. Roteiro metodológico de planejamento - Parque Nacional, Reserva Biológica, Estação Ecológica. Ibama, 2002.

MORSELLO, C.. Áreas protegidas públicas e privadas: seleção e manejo. 2. ed. São Paulo: Annablume, 2006, p.344.

Site do Instituto de Planejamento de Santa Maria. SM EM DADOS - Mapas Google. Disponível em: <http://www.iplansm.net.br/mapasgoogle.php>. Acesso em: 14 jan. 2014.

LEAL, R. P. 2001. Considerações sobre manejo de fauna. In: BAGER, A. (org.) Anais do $1^{\circ}$ Simpósio de Áreas Protegidas - Pesquisa e desenvolvimento sócio-econômico. Pelotas, 2-4 de outubro de 2001. Pelotas: Educat.

SANTA MARIA. Lei Complementar 033, de 29 de dezembro de 2005. Institui a Lei de Uso e Ocupação do Solo, Parcelamento, Perímetro Urbano e Sistema Viário do Município de Santa Maria. Prefeitura Municipal de Santa Maria, Santa Maria, RS, 2005a. Disponível em: <www.santamaria.rs.gov.br/legisis/default.aspx>. Acesso em: 12 out. 2012.

. Lei Complementar 034, de 29 de dezembro de 2005. Dispõe sobre a Política de Desenvolvimento Urbano e sobre o Plano Diretor de Desenvolvimento Urbano Ambiental do Município de Santa Maria. Prefeitura Municipal de Santa Maria, Santa Maria, RS, 2005b. Disponível em: <www.iplansm.net.br/planodiretor.php>. Acesso em: 20 jan. 2014.

. Lei Complementar 072, de 4 de novembro de 2009. Institui a Lei de Uso e Ocupação do Solo, Parcelamento, Perímetro Urbano e Sistema Viário do Município de Santa Maria. Prefeitura Municipal de Santa Maria, Santa Maria, RS, 2009.

Disponível em: <www.santamaria.rs.gov.br/docs/secretarias/ArqSec159.pdf>. Acesso em: 12 out. 2012.

SANTOS, R, F. dos. Planejamento ambiental: teorias e prática. São Paulo: Oficina de Textos, 2004.

SARTORI, P. L. P. Geologia e geomorfologia em Santa Maria. Ciência \& Ambiente, Santa Maria, n. 38, p. 19-42, jan./jun. 2009.

SCHERL, L. M. et al. As áreas protegidas podem contribuir para a redução da pobreza? Oportunidades e limitações. Reino Unido: IUCN, 2006. 60 p. 


\section{Eliane Maria Foleto}

Doutora em Engenharia de Produção pela Universidade Federal de Santa Catarina, mestre em Engenharia Civil pela Universidade Federal de Santa Catarina e graduada em Geografia Licenciatura pela Faculdade de Ciências e Letras Imaculada Conceição. Atualmente é Professora efetiva do Programa de Pós-Graduação em Geografia e do Departamento de Geociências do Centro de Ciências Naturais e Exatas da Universidade Federal de Santa Maria. Participante do Grupo de Pesquisa em Patrimônio Natural, Geoconservação e Gestão da Água (PANGEA).

Rua Benjamin Constant, 784/601, CEP 97050-023, Santa Maria/RS.

E-mail: efoleto@gmail.com

\section{Patrícia Ziani}

Mestranda em Geografia pelo Programa de Pós-Graduação em Geografia da Universidade Federal de Santa Maria e graduada em Geografia Licenciatura pela Universidade Federal de Santa Maria. Bolsista da Coordenação de Aperfeiçoamento de Pessoal de Nível Superior (CAPES). Participante do Grupo de Pesquisa do Patrimônio Natural, Geoconservação e Gestão da Água (PANGEA).

Rua Onze de Julho, 385, CEP: 97105-302, Santa Maria/RS.

E-mail: pathyziani@hotmail.com

Recebido para publicação em abril de 2015 Aprovado para publicação em junho de 2016 